DOI $10.15290 /$ cnisk.2017.01.02.03

DR GRAŻYNA WYDER

Uniwersytet Zielonogórski

\title{
Wielkopolskie działaczki w ruchu narodowo-demokratycznym na terenie Poznańskiego na przełomie XIX i XX wieku. Szkic do działalności politycznej kobiet
}

\begin{abstract}
Streszczenie
W trudnej rzeczywistości ustawowych zakazów i sankcji karnych Polki, kierujac się poczuciem narodowego obowiazku, podejmowały ryzykowną działalność społeczna, charytatywną i polityczną. Działania te, patrzac $z$ perspektywy historycznej, miały duży wpływ na budzenie świadomości narodowej, a ostatecznie na zwycięski zryw niepodległościowy.

Słowa kluczowe: Narodowa Demokracja • partie polityczne • kobieta $\bullet$ Roman Dmowski $\bullet$ Stanisława Niegolewska $\bullet$ Zofia Sokolnicka $\bullet$ Helena Rzepecka • zabór pruski

\section{WIELKOPOLSKA ACTIVISTS IN THE NATIONAL DEMOCRATIC MOVEMENT IN POZNAN AT THE TURN OF THE 19TH AND 20TH} CENTURIES. THE SKETCH OF POLITICAL ACTIVITIES OF WOMEN
\end{abstract}

\section{Abstract}

In the harsh realities of prohibitions and penalties in Poland in the late $1^{\text {th }}$ century XIX, Polish women, guided by a sense of national duty, undertook numerous risky social, charitable and political actions. From a historical point of view, those actions facilitated raising awareness of 
national identity and contributed to the victorious independence movement.

Keywords: National Democracy - political parties • woman • Roman Dmowski • Stanisława Niegolewska • Zofia Sokolnicka • Helena Rzepecka • Prussian annexation

Pierwsze oznaki działalności Ligi Narodowej na teren Poznańskiego dotarły pod koniec XIX w. ${ }^{1}$ Nurt polityczny, z którego później wyłoniła się Narodowa Demokracja nazywana potocznie endecja, wywodził się z Ligi Polskiej (1887-1894). Jego geneza była ściśle związana $z$ zaborem rosyjskim, $z$ czasem jednak ruch rozszerzał się powoli na inne dzielnice. Pomimo że w Poznaniu swą pierwsza jawna organizację pod nazwa Towarzystwa Narodowo-Demokratycznego założono dopiero w 1909 r., to pierwsza próba została podjęta już w 1896 r. przez Romana Dmowskiego i Jana Ludwika Popławskiego, którzy nawiązali kontakty z kilkoma poznańskimi działaczami skupionymi wokół czasopisma „Przegląd Poznański”. Dmowski w traktacie Myśli nowoczesnego Polaka pisał:

Polacy z innych dzielnic, spotykając się z Poznańczykami, przykro bywaja nieraz dotknięci ich poglądami na życie, ich odmiennymi wprost zasadami etycznymi, razi ich suchy realizm, twardość i nawet w pewnej mierze nielitościwość w pojmowaniu spraw życia. Tłumacza to sobie zazwyczaj krótko, uważając wszystko za skutek zniemczenia, gdy tymczasem obok pewnego, znacznego, co prawda, wpływu kultury niemieckiej działała tu o wiele silniej zmiana typu życia, konieczność przystosowania się do warunków nieustannej walki².

Był to bowiem czas intensywnej germanizacji polskiej społeczności w Wielkopolsce, jak i okres obowiązywania dyskryminu-

1 J. Marczewski, Narodowa Demokracja w Poznańskiem 1900-1914, Warszawa 1967, s. 87 i n.

2 R. Dmowski, Myśli nowoczesnego Polaka, Wrocław 2002, s. 28. 
jacej ustawy ograniczajacej prawa kobiet. Wprowadzona 11 marca 1850 r. ustawa o ochronie ustawowej wolności i ustawowego ładu zagrożonych łamaniem prawa do zgromadzeń i stowarzyszeń zakazywała kobietom uczestnictwa w organizacjach o charakterze politycznym. Obowiazywała do 15 marca 1908 r. i na przeszło pół wieku skutecznie ograniczyła możliwość ich aktywności politycznej. Nawiązanie kontaktów z mieszkańcami Poznańskiego nie było łatwe. $Z$ czasem dzięki intensywnej agitacji pozyskano grono sympatyków wśród młodzieży studiujacej na uniwersytetach niemieckich w Berlinie, Wrocławiu i Monachium ${ }^{3}$. W sprawozdaniu $z$ działalności zauważono, że $w$ zaborze pruskim działalność Ligi rozpoczęła sie objeciem przez Grupę Zwiazku Młodzieży Polskiej „Dziennika Berlińskiego” $i$ wystawienia $w$ tym pismie programu demokratyczno-narodowego ${ }^{4}$.

Kilkanaście lat później Dmowski pisał: Prad narodowy ostatniej doby w poczatkach nie wystapił jako coś nowego; był on właściwie reakcja na przeciw narodowy kierunek socjalizmu i na doktryne walki klas, rozbijajaca naród. Ideologia narodowa zdobyła nowy, silny wyraz dopiero $w$ walce $z$ socjalizmem $i$ pokrewnymi mu duchowo dążeniami ${ }^{5}$.

Nowy kierunek polityczny w Poznańskiem został jednak przez większą część społeczeństwa przyjęty z nieufnością, a nawet wrogo. Jak zauważył Lech Trzeciakowski: Tamtejsza opinia publiczna, preferujaca legalne formy walki o utrzymanie odrębności narodowej, bez entuzjazmu odnosiła się do wpół legalnych metod pracy Ligowców $i$ do haseł społecznych $i$ politycznych podważajacych uświęcony solidaryzm6.

W 1899 r. pierwsza grupę partyjna Ligi Narodowej w Poznaniu założył jej działacz, profesor Uniwersytetu Jagiellońskiego,

3 Archiwum Polskiej Akademii Nauk w Poznaniu [APAN Poznań], Spuścizna prof. Z. Wojciechowskiego. Notatki Mariana Seydy dla Zygmunta Wojciechowskiego do pracy o historii Ligi Narodowej, spisane w r[oku] 1932, sygn. P.III-8, odpis, k. 5.

4 Sprawozdanie za rok 1900-1901, „Niepodległość” (styczeń 1934 - czerwiec 1934), t. 9 , s. 112.

5 A. (Senior) [R. Dmowski], Poczatki nowoczesnego obozu narodowego w Polsce, „Myśl Narodowa” 1936, nr 47, s. 1.

${ }^{6}$ L. Trzeciakowski, Pod pruskim zaborem 1850-1918, Warszawa 1973, s. 245. 
Wincenty Lutosławski7 ${ }^{7}$ W jej skład weszli: Bernard Chrzanowski, dr Felicjan Niegolewski, jego żona Stanisława Niegolewska oraz Helena Rzepecka8.

W 1903 r. do Ligi wstapiła Zofia Sokolnicka wraz z grupa znanych działaczy 9 . Tym samym w ruchu narodowym w Poznańskiem odnotowano uczestnictwo trzech kobiet, co nie było może wielkością imponująca, ale wobec zakazu działalności politycznej świadczyło o powolnym przekraczaniu barier politycznych, a także mentalnych. Wspomniane działaczki były bowiem wybitnymi aktywistkami społecznymi. Działały w większości społecznych organizacji kobiecych w Poznaniu. Należały do elity kulturalnej miasta, a ich wpływ na rzesze kobiet skupionych w różnorodnych instytucjach dobroczynnych był znaczny.

Liczba członków wzrastała powoli i na przełomie 1903/1904 r. organizacja liczyła osiemnaścioro działaczy ${ }^{10}$. Ten powolny wzrost Bernard Chrzanowski tłumaczył po latach:

Tu praca jednak najpierw kulała; nie było jedności zapatrywań, bo najważniejszym kryterium przyjęcia było (...) dążenie do niepodległości: a tu członków mało, a wskazań politycznych kilka, już to przeciw wszystkim, już to przeciw najniebezpieczniejszym $z$ zaborców; lecz, przeciw komu z nich? Jaka ich kolej? - Dopiero też, gdy Prusak nas złączył groza utraty ziemi, prawem osadniczym i wywłaszczeniem - zawrzała praca ${ }^{11}$.

7 S. Kozicki, Historia Ligi Narodowej (okres 1887-1907), Londyn 1964, s. 155; Sprawozdanie $z$ działalności Ligi w r[oku] 1895/1896, „Niepodległość” 1933, t. 7, s. 273; T. Czyżowski, Wincenty Lutosławski (1863-1954), Polski Słownik Biograficzny [PSB], t. 18, red. E. Rostworowski, Wrocław 1973, s. 153-156.

8 J. Marczewski, op. cit., s 106.

9 Sprawozdanie $z$ działalności Ligi Narodowej od 1 lipca 1903 do 1 lipca 1904, „Niepodległość" 1934, t. 10, s. 125, 127-130; S. Kozicki, op. cit., s. 190.

10 Sprawozdanie $z$ działalności Ligi Narodowej od 1 lipca 1903 do 1 lipca 1904, „Niepodległość" 1934, t. 10, s. 128.

11 Cyt. za: J. Karwat, Od idei do czynu. Myśl i organizacje niepodległościowe $w$ Poznańskiem $w$ latach 1887-1919, Poznań 2002, s. 145; więcej o działalności B. Chrzanowskiego zob. G. Łukomski, Bernard Chrzanowski (1861-1944): biografia Polaka zachodniokresowego, Poznań-Opalenica 2005. 
W 1899 r. założono Towarzystwo Wykładów Ludowych im. Adama Mickiewicza, na czele którego stanęli: Chrzanowski, dr Antoni Chłapowski, Joachim Sołtys, B. Krysiewicz, dr Jan Nepomucen Szuman i dr Tomasz Drobnik.

$Z$ czasem zaczęto rozszerzać swe wpływy na Towarzystwo Czytelni Ludowych, gdzie od 1898 r. członkiem zarządu był Chrzanowski12. Utrzymywano dobre stosunki z Towarzystwem Kobiecym „Warta”, w prace której zaangażowane były działaczki wchodzace do kierownictwa Narodowej Demokracji w Poznańskiem ${ }^{13}$. Chrzanowski wspomagał Towarzystwo pomoca prawna, wcześniej zaś uczestniczył w „narodzinach” „Warty”. Jak nadmienił we wspomnieniach:

Na biurku mojem stoi dotychczas kałamarz z data „1894”, ofiarowany mi przez „Wartę”; Niewiasty nasze, panienki i mężatki zabrały się po roku 1891 do uczenia dzieci z ludu polskiego czytania i pisania. Chciały się organizować. Poradziłem, aby utworzyły jawne towarzystwo podając jako jego cel wzajemne obopólne kształcenie się w języku, literaturę i historii Polski ${ }^{14}$.

Pierwszy zjazd członków Ligi Narodowej zaboru pruskiego odbył się w Poznaniu w kwietniu 1901 r. ${ }^{15} 1$ grudnia 1903 r. działacze Ligi przejęli pismo „Praca”16. W 1904 r. na licytacji zakupiono

12 Zbiory Specjalne Biblioteki Raczyńskich w Poznaniu [Zb.SBR], sygn. 1375,

B. Chrzanowski, Z Towarzystwa Czytelni Ludowych, „Pamiętniki”, cz. 1.

13 Marczewski w swej pracy napisał, że zdobyli rozstrzygajacy wpływ na „Warte” (J. Marczewski, op. cit., s. 129-130).

14 Zb.SBR, sygn. 1375/e-IV, B. Chrzanowski, Z Towarzystwa Czytelni Ludowych, „Pamiętniki”, cz. 1, k. 28.

15 Sprawozdanie $z$ działalności Ligi Narodowej za rok 1900-1901, „Niepodległość" (styczeń 1934 - czerwiec 1934), t. 9, s. 112-113; APAN Poznań, Spuścizna prof. Z. Wojciechowskiego. Notatki Mariana Seydy dla Zygmunta Wojciechowskiego do pracy o historii Ligi Narodowej, spisane w r[oku] 1932, sygn. P.III-8, odpis, s. 6-8; Archiwum Zarządu Okręgowego ZBOWiD w Poznaniu, sygn. 800, L. Gomolec, Przygotowania do powstania wielkopolskiego.

16 W. Jakóbczyk, Prasa w Wielkopolsce (1859-1918) [w:] Prasa polska w latach 1864-1918. Historia prasy polskiej, red. J. Łojek, Warszawa 1976, s. 193. 
upadajace pismo „Goniec Wielkopolski”17, którego założycielem i redaktorem był dr Ludwik Rzepecki. Wnioskując $z$ anonsu prasowego, prawna właścicielka pisma była jego żona Romana Rzepecka ${ }^{18}$, a córka Helena wraz z synem Karolem współredagowali pismo ${ }^{19}$. Rzepecka pozostała w redakcji do 1904 r. Pierwotnie pismo kierowane było do wszystkich stanów społecznych, nie posiadało wyraźnie sprecyzowanego programu, a w założeniach programowych zapisano, że nie będzie służył żadnemu stanowi wyłacznie, tylko wszystkim razem ${ }^{20}$. Popierano pracę organiczna, a redakcja - jak zaznaczył Witold Jakóbczyk - zwalczała ostro polityke zaborcza, zarówno germanizacyjna, jak i rusyfikacyjna. Przestrzegała przed lojalizmem i orientacja na którekolwiek $z$ mocarstw rozbiorowych, wierzac $w$ odrodzenie niepodległej Polski (...). W dziedzinie społecznej zwalczała wszelkie formy walki klasowej, a rozwiazanie kwestii społecznych widziała we wzmożeniu działalności charytatywnej21. Na łamach "Gońca Wielkopolskiego” opublikowano cykl artykułów Demokracja a polskie społeczeństwo, w których wyjaśniano znacznie partii.

W myśl wspomnianej powyżej ustawy zabraniającej kobietom uczestnictwa $\mathrm{w}$ organizacjach o charakterze politycznym pod groźba ich rozwiązania, więzienia czy kar pieniężnych, nawet tak nikła liczba działaczek w ruchu narodowym stanowiła już pewien

17 Archiwum Państwowe w Poznaniu [APP], Akta betreffend den „Goniec Wielkopolski”, Wycinki prasowe Polizei Präsidium, sygn. 7266 (w tym czasie pismo liczyło 3723 abonentów).

18 Ks. Klementowski, Śp. Romana z Gex’sów Rzepecka, „Kurier Poznański” [KP] 1918, nr 72, s. 3; K. Męczyńska, Romana Rzepecka, jej córki i gosposia, „Kronika Miasta Poznania" 2011, nr 1, s. 84 i n.

19 Romaine $z$ Gex Rzepecka, w spolszczonej wersji Romana, pochodziła $z$ rodziny szwajcarsko-francuskiej. Do Poznania przyjechała w 1850 r. w poszukiwaniu pracy. Szybko poznała literaturę polską i opanowała język polski, którego z czasem zaczęła uczyć. W 1857 r. wyszła za mąż za Ludwika, wydawcę i redaktora początkowo „Oświaty” (1866-1867), później tygodnika „Warta” (1875-1883), a następnie „Gońca Wielkopolskiego" (1877-1894). W swym długim i aktywnym życiu była członkiem polskich organizacji kobiecych, autorka podręcznika Pierwsze poczatki czytania i języka francuskiego dla użytku polskich dzieci wydanego w Poznaniu w 1864 r. Zmarła 23 marca 1918 r. w wieku 88 lat (KP 1918, nr 72, s. 3; K. Męczyńska, op. cit., s. 84).

20 W. Jakóbczyk, op. cit., s. 193.

21 Ibidem, s. 183. 
przełom mentalny. Kobiety, wolno, bo wolno, ale przełamywały opór przed włączaniem się $\mathrm{w}$ działalność polityczną. Zwieńczeniem łamania owych hamulców był udział jako posłanek 141 Wielkopolanek w Polskim Sejmie Dzielnicowym w Poznaniu, który odbył się w dniach 3-5 grudnia 1918 r. Ta liczba aktywistek nie doczekała się jednak obszerniejszego opracowania naukowego, chociaż $\mathrm{w}$ wielu studiach na temat historii rozwoju ruchu narodowego w Poznańskiem przytacza się ich nazwiska.

Wymienione powyżej działaczki weszły w skład ścisłego kierownictwa Ligi Narodowej w Poznańskiem. Nie były osobami anonimowymi, tworzyły społeczny aktyw kobiecy. Helena Rzepecka ${ }^{22}$, która do organizacji wstapiła wraz ze Stanisławą Niegolewska, żoną Felicjana, miała wówczas 36 lat. Była znaną i cenioną nauczycielka. O jej działalności stricte politycznej wiadomo niewiele. Od 1900 r. była działaczka tajnego Towarzystwa Tomasza Zana w Poznaniu, a od 1911 r. opiekowała się jego członkami. Była również współautorką wstępu do programu Ligi w zaborze pruskim. W jej mieszkaniu przy ul. św. Marcina zbierała się ówczesna młodzież akademicka i młodsza inteligencja zawodowa. Tadeusz Szulc w swych wspomnieniach zauważał, że zjazdy poznańskiego „Zetu”, tajnego zwiazku młodzieży polskiej, odbywały sie przeważnie $w$ mieszkaniu Heleny ${ }^{23}$. Dom jej - jak pisano w „Kurierze Poznańskim” - stał się ogniskiem ruchu zawodowego, $w$ którym rodza się różne projekty i czyny, $w$ których wielkim płomieniem pali się znicz myśli polskiej i miłości sprawy narodowej, $z$ którego następnie umiłowania te szeroka fala szly $w \dot{z} y c i e ~ i$ realizowaty sie dla dobra sprawy ${ }^{24}$. Przez wiele lat Rzepecka zmagała się $z$ chorobą żołądka i płuc, co zapewne nie pozwoliło jej na pełne angażowanie się $\mathrm{w}$ stresującą działalność polityczną. Swe przekonania realizowała poprzez pracę oświatowa, społeczna,

22 L. Słowiński, Helena Rzepecka, PSB, t. 34, red. H. Markiewicz, Wrocław 1992-1993, s. 18-19.

23 T. Szulc, W Poznaniu i wkoło niego. Wspomnienia poznańskiego lekarza, Poznań 1995, cyt. za: K. Męczyńska, op. cit., s. 88.

${ }^{24}$ Śp. Helena Rzepecka, KP 1916, nr 117, s. 3. 
charytatywna. Jej dokonania przy tak słabym zdrowiu były imponujące i, jak zaznaczyła Katarzyna Męczyńska, w jej życiu:

zmieściło się tyle najrozmaitszych działań, że trudno jej nie podziwiać: praca dziennikarska, wydawnicza i pisarska, nauczanie języka polskiego i historii, organizowanie ogródków i wakacji dla dzieci, wychowanie patriotyczne, wspieranie naukowych ambicji młodych kobiet, działalność w stowarzyszeniach kobiecych ${ }^{25}$.

Helena Rzepecka urodziła się 24 maja 1863 r. w Poznaniu. Po ukończeniu szkół i uzyskaniu dyplomu nauczycielskiego $w$ domach najpoważniejszego obywatelstwa wielkopolskiego (...) wszczepiała $w$ serca uczennic najlepsze tradycje patriotyczne ${ }^{26}$. Jednocześnie na łamach redagowanego przez siebie pisma rozpowszechniała artykuły poświęcone sprawom wychowania młodzieży, szkolnictwa i oświaty. Aktywnie działała w sekcji odczytowej Towarzystwa „Warty”27, uczestniczac w zebraniach i wiecach, wygłaszając odczyty o literaturze, historii polskiej, ale i o działalności kobiet. Jak zauważano:

Był to typ kobiety wyjątkowo inteligentnej i dzielnej pod każdym względem (...). Umysł posiadając na wskroś samodzielny, męski prawie i pełen inicjatywy, przystępowała do wszelkich zamierzeń $z$ doskonała świadomościa celu, $z$ goracem umiłowaniem sprawy i energia nieprzeciętna ${ }^{28}$.

Aktywnie włączyła się w ruch emancypacyjny kobiet. W 1899 r. wspólnie $z$ Anielą Tułodziecką wzięła udział w Zjeździe Kobiet Polskich w Zakopanem, zwołanym $\mathrm{z}$ inicjatywy działaczek krakow-

25 K. Męczyńska, op. cit., s. 88.

26 L. Słowiński, $Z$ dziejów walki o tożsamość narodowa pod pruskim zaborem. Działalność oświatowa i społeczna Heleny Rzepeckiej (1863-1916), „Kronika Miasta Poznania" 1994, nr 3/4, s. 438; Idem, Działalność oświatowa $i$ społeczna Heleny Rzepeckiej (1863-1916) [w:] L. Słowiński, Będziem Polakami: studia $z$ dziejów edukacji narodowej $w$ Wielkim Księstwie Poznańskim, Poznań 1995, s. 127.

27 Zb.SBR, Akta Towarzystwa Warta, sygn. 1034, Protokół z[e] zwyczajnego posiedzenia Towarzystwa „Warta” $z$ dnia 2 października 1895, k. 15.

28 Śp. Helena Rzepecka, KP 1916, nr 117, s. 3. 
skich. Rzepecka wygłosiła na nim referat pt. Obraz działalności kobiet $w$ Poznaniu przygotowany przez przewodniczaca "Warty” Tułodziecką29.

10 maja 1908 r. na wiecu kobiet w Poznaniu, czwartym z kolei zorganizowanym przez „Wartę" w odpowiedzi na wprowadzenie ustawy o stowarzyszeniach, wygłosiła mowę zatytułowana Zadania Polki wobec dwóch naszych ustaw30. Rozpatrujac regulacje prawne dyskryminujace rodaków, przypominała o obowiazkach i zadaniach stojących przed Polkami. Podkreślała konieczność trwania na wyznaczonym narodowym posterunku. Zwracała uwage na unormowania zezwalające kobietom na działalność w organizacjach społeczno-politycznych. Zachęcała słuchaczki, by wstępowały do istniejących stowarzyszeń lub same je zakładały, byśmy naprzód nabyly tej elementarnej podstawy, ku zrozumieniu urządzeń państwa, miasta i gminy, $w$ której żyjemy ${ }^{31}$.

Rzepecka weszła w skład komisji kursów społeczno-ekonomicznych ${ }^{32}$, w ramach której brała udział w prowincjonalnych kursach dla kobiet ${ }^{33}$, uświadamiając Polkom nowe możliwości.

Wobec paragrafu językowego $\mathrm{w}$ ustawie o stowarzyszeniach i zebraniach powinny kobiety korzystać $z$ tego, co przez tą ustawę zyskały. Moga więc brać udział w zebraniach wyborczych i nawet przemawiać na nich. Moga należeć do wszelkich stowarzyszeń, nawet politycznych. Tam wolno nam mówić po polsku. (...). Budźmy ducha narodowego ${ }^{34}$.

Aktywność społeczno-polityczna nie była jedynym polem działalności Heleny. $Z$ zaangażowaniem oddawała się pracy dzienni-

${ }^{29}$ Zakopane-Zjazd, KP 1899, nr 188, s. 3; nr 190, s. 3.

30 Walny wiec kobiet $w$ Poznaniu, „Dziennik Poznański” 1908, nr 109, s. 5; pełny tekst mowy zob. KP 1908, nr 112, s. 2-3, cz. 1; KP 1908, nr 113, s. 3, cz. 2.

31 Mowa panny Heleny Rzepeckiej, cz. 2: Zadanie Polki wobec dwóch nowych ustaw wygłoszona na wiecu kobiet $w$ dniu 10 maja, "Głos Wielkopolanek” [GW] 1908, nr 9, s. 1-5.

32 Pierwszy kurs spoleczny dla kobiet, GW 1908, nr 36, s. 2.

33 Ibidem.

34 Słowa te wypowiedziała na walnym wiecu kobiet w Poznaniu 12 maja 1908 r. (zob. „Dziennik Poznański” 1908, nr 109, s. 5). 
karskiej i literackiej. W latach 1910-1914 redagowała miesięcznik literacko-muzyczny „Śpiewak”, organ Związku Kół Śpiewaczych na Rzeszę Niemiecka, a od 1911 r. dodatek kulturalny do „Dziennika Poznańskiego” - „Literatura i Sztuka”. Pisywała do „Kuriera Poznańskiego”, krakowskiej „Straży Polskiej” i warszawskiego „Bluszczu”35.

W trosce o patriotyczne wychowanie dziewcząt polskich otworzyła pensję dla panien. Wnioskując $z$ listu jednej z uczennic, Heleny Rogalanki (1894-1948), praca pedagogiczna nie była jednak jej powołaniem. Stanowiła cenne źródło dochodu, gdyż nauka języka polskiego była odpłatna ${ }^{36}$.

W 1911 r. ukazało się dzieło jej życia - dwutomowy, bogato ilustrowany podręcznik do nauki domowej Ojczyzna $w$ piśmie i pomnikach ${ }^{37}$. Jak zauważała w przedmowie: Ksiażka niniejsza pragnie pobudzić do pracy nad wykształceniem narodowem młodzieży i samoukom $w$ części, chociaż zastapić to, czego im niestety nie daje dzisiaj słowo nauczycielskiego wykładu38.

W Poznaniu wysoko ceniono jej dokonania publicystyczne, jak i polityczne. Stefan Cegielski twierdził, że $z$ nikim tak jak $z$ nia, nie rozmawia się tak dobrze i zajmujaco ${ }^{39}$. Jej działalność nie uszła uwadze niemieckiej policji. W policyjnych aktach odnotowano:

Helena Rzepecka stoi na tym samym gruncie politycznym, co jej brat. Podziela ona jego poglądy, włada zręcznie słowem mówionym i pismem w prasie i na zebraniach. Jest tutaj znana jako energiczna i zdeterminowana agitatorka sprawy polskiej ${ }^{40}$.

Zmarła 22 maja 1916 r. W nekrologu przypominano:

\footnotetext{
35 L. Słowiński, $Z$ dziejów walki..., op. cit., s. 444.

36 K. Męczyńska, op. cit., s. 92-93. Kwartalny koszt nauki wynosił 25 marek.

${ }^{37}$ H. Rzepecka, Ojczyzna w piśmie i pomnikach, t. 2, Poznań 1911.

38 Ibidem.

39 P. Cegielska, Przechadzki po mieście: z moich wspomnień, Poznań 1997, s. 121.

40 APP, Polizei Präsidium Posen [Prezydium Policji w Poznaniu], sygn. 3681, Helena Rzepecka.
} 
Legła bojowniczka niestrudzona narodowego jutra. Rządziła dusza swa niezachwiana wiara w siły własne narodu, swa niezłomną nadzieją wolności. Legła na posterunku w chwili przedświtu ${ }^{41}$.

Niewiele wiemy o działalności w tym okresie żony dr. Felicjana Niegolewskiego Zofii Stanisławy Heleny z Jasieńskich. Wstępujac do Ligi w 1899 r., miała 20 lat i była niedawno poślubiona małżonką (ślub odbył się 3 marca tego roku w Warszawie w parafii św. Aleksandra). Urodziła się 8 stycznia 1879 r. ${ }^{42}$ Jej obecność w Narodowej odnotowuja wszystkie opracowania. Wspomagała działalność męża, o czym świadczy zarówno fakt wstapienia do Ligi, jak i jej aktywność w Towarzystwie Naukowej Pomocy dla Dziewczat 43 . O jej czynnym udziale w pracach partii informowała prasa w nekrologu zmarłego 8 stycznia 1919 r. Felicjana, wspominając i o dzielnej towarzyszce ${ }^{44}$. Za odwage i zaangażowanie została odznaczona Krzyżem Walecznych45. Po śmierci męża w 1925 r. powtórnie wyszła za mąż za Mariana Kiniorskiego, endeckiego polityka, ziemianina, właściciela majątku w Suchodębie (powiat Kutno), w latach 1922-1927 senatora w sejmie II RP $z$ ramienia Zwiazku Ludowo-Narodowego. Zmarła w wieku 75 lat, 16 maja 1954 r. w Szczecinie ${ }^{46}$.

Z działaczek Ligi bardziej znana jest Zofia Sokolnicka, posłanka do sejmu dwóch kadencji (1919 i 1922 r.). W chwili przystapienia do organizacji miała 24 lata. Urodziła się 15 maja 1878 r.

${ }^{41}$ Ku uczczeniu śp. Heleny Rzepeckiej, KP 1916, nr 118, s. 3.

42 Hasło: Niegolewscy, h. Grzymała [w:] Teki Dworzaczka. Materiały historyczno-genealogiczne do dziejów szlachty wielkopolskiej XV-XX wieku [online], KórnikPoznań 2004, poz. 754 [Dostęp: 03.05.2017]. Dostępny w World Wide Web: $<$ http://teki.bkpan.poznan.pl/>.

43 Towarzystwo Przyjaciół Wzajemnego Pouczania się i Opieki nad Dziećmi „Warta" powstało 29 maja 1894 r. w Poznaniu. Z jednej strony była to jawna organizacja zajmująca się organizacja opieki nad ubogimi i upośledzonymi dziećmi $z$ Poznania, $z$ drugiej zaś na tajnych kompletach uczyła polskie dzieci historii i języka (zob. G. Wyder, $Z$ dziejów walki o tożsamość narodowa-tajne stowarzyszenie Kobiet „Warta” [w:] Polacy - Niemcy - Pogranicze. Studia Historyczne, red. nauk. G. Wyder, T. Nodzyński, Zielona Góra 2006, s. 183-200).

${ }^{4}$ Śp. Felicjan Niegolewski, KP 1919, nr 7, s. 3.

45 Marian Kiniorski [w:] Ziemianie polscy XX $w$. Słownik biograficzny, t. 2, red. J. Leskiewiczowa, Warszawa 1994, s. 93.

46 Ibidem. 
w Krakowie, w rodzinie ziemiańskiej o dużych tradycjach niepodległościowych. Jej biografowie dowodza, że po ukończeniu pensji Wyższej Szkoły Żeńskiej A. Danyszówny w Poznaniu podjęła studia na Uniwersytecie Jagiellońskim ${ }^{47}$. W Krakowie ukończyła również studia muzyczne ${ }^{48}$, choć badania nie potwierdzaja tego faktu. W zachowanych katalogach studentów Wydziału Filozoficznego (istniały wówczas dwa - filozoficzny i lekarski) Sokolnicka nie figuruje ${ }^{49}$. Przypuszczalnie $\mathrm{w}$ tym okresie uczęszczała na założone przez Adriana Baranieckiego Wyższe Kursy dla Kobiet, które stanowity rodzaj żeńskiego uniwersytetu $w$ "miniaturze"50 i na które w kolejnych latach organizowała wyjazdy dziewcząt51. Kursy dawały kobietom wyższe wykształcenie humanistyczne i artystyczne, a ponadto, legitymując się świadectwem $z$ pozytywnymi egzaminami, mogły pełnić funkcje prywatnych nauczycielek $\mathrm{w}$ zaborze pruskim ${ }^{52}$. Tam też prawdopodobnie Sokolnicka nawiazała pierwsze kontakty $z$ działaczami endecji. Ewa Maj podaje, że studia filozoficzne odbyła na uniwersytecie we Lwowie ${ }^{53}$. Po powrocie zajęła się nauczaniem, prowadząc $z$ siostrami Lucyna i Marią oraz matką Stanisława $z$ Moszczeńskich w swym 12-pokojowym mieszkaniu przy ul. Ogrodowej 13 prywatne Gimnazjum Żeńskie. Witold Sokolnicki, wychowanek „trzech ciotek”, tak napisał o Zofii w swych pamiętnikach: Niezależnie od pracy pedagogicznej Zosia zajmowała się czynnie polityka, należała do Naro-

47 Z. Kaczmarek, Sokolnicka Zofia, Wielkopolski Słownik Biograficzny [WSB], red. A. Gąsiorowski, Warszawa-Poznań 1981, s. 682-683.

48 Ibidem; Parlament Rzeczypospolitej Polskiej 1919-1927, red. H. Mościcki, W. Dzwonkowski, Warszawa 1928, s. 112.

49 U. Perkowska, Studentki Uniwersytetu Jagiellońskiego w latach 1894-1939. W stulecie immatrykulacji pierwszych studentek, Kraków 1994, s. 92-93; zob. też: W. Molik, $Z$ badań nad studiami uniwersyteckimi Wielkopolanek na przełomie XIX $i$ XX wieku [w:] Kobieta i edukacja na ziemiach polskich w XIX $i$ XX wieku, t. 2, cz. 2, red. A. Żarnowska, A. Szwarc, Warszawa 1992, s. 25-30.

50 J. Kras, Wyższe kursy dla kobiet im. A. Baranieckiego w Krakowie 1968-1924, Kraków 1927, s. 108.

51 Ibidem, s. 109.

52 Ibidem, s. 110.

53 E. Maj, Wzorce aktywności kobiet w Narodowej Demokracji (1893-1939) [w:] Drogi kobiet do polityki (na przestrzeni XVIII-XXI wieku), red. T. Kulak, M. Dajnowicz, Wrocław 2016, s. 153. 
dowej Demokracji, toteż miała częste kontakty z Dmowskim, który często bywat $w$ „saloniku czerwonym” przy ul. Ogrodowej $13^{54}$. Logicznym następstwem było jej wstapienie do aktywizującej się w Poznaniu Ligi Narodowej55. Podjęła również działalność w tajnej organizacji młodzieży gimnazjalnej i akademickiej w Towarzystwie Tomasza Zana.

Nieznany $z$ nazwiska tajny informator policji, donosząc o organizacji i działalności tajnego zwiazku, zauważył, że powołano silna organizację, która objęła wszystkie prawie instytucje ksztatcace $^{56}$. W jego ocenie najsilniejszym związkiem był poznański, który liczył około 120 członków. Informował też o organizacji uczennic, która miała nieco inny charakterze niż męska. Pisał:

Polskie zajęcia prowadzone sa $\mathrm{w}$ godzinach popołudniowych przez polskie nauczycielki pod nazwą robótki ręczne. Tak to odbywa się u Danysza i Warnke. Do tych lekcji dopuszcza się jednak tylko bardziej uświadomione dziewczynki. Taka lekcja odbywa się przeważnie wtedy, kiedy w klasach nie ma innych zajęć, ale i w prywatnych mieszkaniach maja pensjonarki swoje godziny - na przykład u lekarza - dentysty Paleńskiego. Widziałem jak tam z polskimi księżmi szły regularnie w czwartek i poniedziałek Stanisława Szenic ze swoja młodsza siostra i panna Man[n]. Ruchem tym kieruje panna Rzepecka i panny Sokolnickie ${ }^{57}$.

Sokolnicka w wydanych już w niepodległej Polsce wspomnieniach napisała:

Przed 20 laty ścisłym złączona węzłem z Towarzystwa Tomasza Zana we współpracy $z$ długim szeregiem kolejno po sobie działajacych zastępów młodzieży filareckiej i filomackiej, mam w umyśle

\footnotetext{
54 Materiały Archiwum Rodziny Sokolnickich, Pamiętnik Witolda Sokolnickiego, s. 13 (zbiory autorki).

55 Zb.SBR, sygn. 1375/I a, B. Chrzanowski, Wspomnienie, cz. 1, k. 167.

56 B. Halczak, Towarzystwo Tomasza Zana w latach 1899-1914, Zielona Góra 1996, s. 84.

57 Ibidem, s. 90.
} 
i w sercu wyraźnie odbity obraz rozwoju i działalności tej organizacji oraz owoców jej misji58.

W jej ocenie TTZ $w$ okresie niewoli podtrzymywało $w$ nim [społeczeństwie] narodowego ducha, polska kulture wewnętrzna i zewnętrzna $w$ domach naszych, kulture językowa, znajomość i umiłowanie ojczystych dziejów, piśmiennictwa, tradycji, obyczajów. Ono wychowywało i dało spośród siebie społeczeństwu najlepszych i najdzielniejszych pracowników i szermierzy we wszystkich dziedzinach życia narodowego ${ }^{59}$. Podkreśliła, że członkowie Towarzystwa, studiując na niemieckich uniwersytetach, promieniowali idee narodowe (...) wśród kolegów i polskiego wychodźstwa ${ }^{60} . Z$ dumą zaznaczyła, że nie zgubiła polska młodzież „złotego rogu", który Opatrzność dała jej w rękęe1.

Od 1912 r. korzystała z pomocy Zetowców przy zabezpieczeniu bezpieczeństwa tajnych wykładów naukowych organizowanych i prowadzonych przez nią dla inteligencji Poznańskiego oraz zaproszonych na nie prelegentów. Wykłady odbywały się w Poznaniu, Gnieźnie i Inowrocławiu przy bardzo licznym udziale inteligencji (...). Wykładali twórcy i krzewiciele polskiej nauki, przeważnie profesorowie wszechnicy jagiellońskiej i lwowskiej, lecz incognito na zewnatrz, gdyż policja pruska nie dopuszczała do Wielkopolski „obcokrajowców” Polaków62. Młodzi członkowie Zetu pełnili wówczas tzw. straż bezpieczeństwa ${ }^{63}$.

W 1904 r. była członkiem komitetu przygotowujacego wiec kobiet polskich $z$ okazji 10-lecia Towarzystwa Wzajemnego Pouczania i Opieki nad Dziećmi „Warta”. Był to jednocześnie protest wobec uroczyście obchodzonego przez Niemców jubileuszu powołania niemieckiej organizacji Hakata. We wrześniu 1905 r. weszła również $\mathrm{w}$ skład powstałej $z$ inicjatywy działaczy endeckich orga-

58 Z. Sokolnicka, O pracy tajnej Towarzystwa Tomasza Zana pod jarzmem pruskim. Kilka wspomnien, seria „Biblioteka Filomacka”, t. 3, Warszawa 1921.

59 Ibidem, s. 57.

60 Ibidem.

61 Ibidem, s. 59.

62 Ibidem, s. 60.

63 Ibidem. 
nizacji „Straż”. Razem z paniami Kapuścińską, Rzepecką i Tułodziecka podjęła pracę w sekcji kulturalnej64.

Cały czas aktywnie działała w Towarzystwie Wzajemnego Pouczania i Opieki nad Dziećmi „Warta”, które prowadziło tajne nauczanie języka ojczystego i historii. $Z$ racji posiadanych kwalifikacji włączała się w prace sekcji pedagogicznej65, a przez pięć miesięcy (30 kwietnia - 24 września 1897 r.) była jej sekretarką66. Wobec braku odpowiedniej literatury pedagogicznej opracowała, wraz z Marią Brownsford, podręcznik dla nauczycielek Jak uczyć dzieci czytać i pisać po polsku67.

W czasie I wojny światowej, od 1915 r., pełniła funkcję łączniczki pomiędzy ośrodkiem poznańskim a powołana w tym roku Centralną Agencja Polska w Lozannie, a następnie Komitetem Narodowym Polskim w Paryżu68. Wyjazdy Sokolnickiej do Szwajcarii były możliwe dzięki zezwoleniu policji na leczenie w klinice okulistycznej, gdyż groziła jej utrata wzroku. W ten sposób udało jej się wyjechać trzykrotnie69.

Jednym $z$ podstawowych zadań agencji lozańskiej było informowanie państw zachodnich o sprawie polskiej i rozwoju bieżących wypadków w kraju, co nie byłoby możliwe bez kontaktów z Polską. Informacje $z$ Poznańskiego przekazywała m.in. Sokolnicka. Jako doświadczona emisariuszka przygotowywała innych emisariuszy. Bogdan Hulewicz w książce Wielkie wczoraj w małym kręgu, wspominając współpracę z Sokolnicka, napisał:

Kilkakrotnie wyjeżdżałem na urlopy okolicznościowe do Poznania. Za każdym razem przewoziłem instrukcje polskich czynników

${ }^{64}$ Zb.SBR, sygn. 1375/I a, B. Chrzanowski, Wspomnienie, cz. 1, k. 155-157.

65 Zb.SBR, Akta Towarzystwa Warta, sygn. 1034.

66 Ibidem, Protokół z „Pogadanki Pedagogicznej” odbytej dnia 30-go kwietnia [18]97 r. w „Czytelni dla Kobiet”.

67 Zb.SBR, Brownsford Maria (21 III 1855 w Lubowiczkach pow. Gniezno - 29 X 1924 w Bialczu); P. Cegielska, op. cit., s. 109; Śp. Zofia Sokolnicka, KP 1927, nr 94 , s. 1.

68 Z. Dworecki, Poznańskie i Piłsudski, Poznań 2008, s. 63.

69 Pamiętnik Witolda Sokolnickiego, cyt. za: B. Serwatka, Zofia Sokolnicka - nauczycielka $i$ działaczka spoleczna (1878-1927), praca mag., Uniwersytet im. Adama Mickiewicza w Poznaniu, Poznań 1993, s. 64. 
politycznych do Poznania i z Poznania do Koła Międzypartyjnego. Wszystkie nosiły charakter antyniemiecki, ale niczego pisemnego przy sobie nie miałem nigdy. Zofia Sokolnicka pilnowała mnie i egzaminowała, czy potrafię powtórzyć w Warszawie to, czego musiałem nauczyć się na pamięć w Poznaniư70.

Jej niezwykła umiejętność pamięciowego opanowywania zaszyfrowanych wiadomości stała się wręcz przysłowiowa. Musiała się tego nauczyć zmuszona względami bezpieczeństwa, albowiem wraz $z$ cała rodzina znajdowała się pod ścisłym nadzorem policji, o czym świadczy wyciag $z$ aktów personalnych policji pruskiej71. W artykule prasowym Alfabet Zofii Sokolnickiej, opublikowanym w dziesięciolecie odzyskania przez Polskę niepodległości, oddając atmosferę tamtych dni, pisano:

Listopad. W czerwonym saloniku pań Sokolnickich zgromadziło się kilka kobiet. Jest późny wieczór, drzwi dobrze zamknięte. „Koło” konspirantek radzi cicho, zgodnie, pilnie. Panie Wrzesińska, Rydlewska, Brzeska, Kapuścińska i kilka innych. (...). W gabinecie pana Wrzesińskiego nad maszyna do pisania pochylają się zapatrzone w trudny do odcyfrowania rękopis panie Wrzesińska i Brzeska. (...) Nici tajne, nici subtelne, nici cudownie, madrze powiazane łączą daleką Lozannę z Poznaniem. Panie Wrzesińska i Brzeska układają tajny alfabet, kombinuja, poprawiaja, przepisują. A potem odbywa się lekcja. To panna Sokolnicka uczy się na pamięć alfabetu, tajnego szyfru, z pomoca którego pośle listy z Szwajcarii do Poznania do matki, do siostry. Gdzieś tam daleko myśla i pracuja Dmowski, Seyda i inni, a tu na miejscu współdziałają $z$ nimi anonimowo mało komu znane panie ${ }^{72}$.

70 B. Hulewicz, Wielkie wczoraj w małym kręgu, Warszawa 1968, s. 98.

${ }^{71} Z$ Archiwum Zofii Sokolnickiej. W dziesięciolecie Traktatu Wersalskiego, KP 1929, nr 294, s. 7 [w tłumaczeniu własnym: „Wobec pani Stanisławy Sokolnickiej, jak i panien Lucyny i Zofii Sokolnickiej, zamieszkałych tu, ul. Ogrodowa 13, ostatnio w Lozannie (Szwajcaria) hotel Montreux, wprowadza się rewizję wszelkich przesyłek prasowych, ponieważ sa podejrzewane o wroga działalność. Prosi się Dyrekcję Cesarskiej Poczty Głównej, aby powiadomiła urzędy pocztowe i przesyłała tutejszej policji zarekwirowane rzeczy. Prezydium Policji, Oddział Specjalny"].

72 Alfabet Zofii Sokolnickiej, KP 1928, nr 518, s. 7. 
O działalności partyjnej współpracujących z Sokolnicką kobiet literatura przedmiotu, jak i zachowane materiały źródłowe nie wspominaja, ale prawdopodobnie sympatyzowały $z$ partia $i$ jej działaniami. Wtajemniczone $\mathrm{w}$ konspiracyjna pracę grono kobiet nie było jednak bezimienne. Były to wybitne działaczki zasłużonego także na polu politycznym Towarzystwa „Warta”.

Wyuczone raporty Sokolnicka „przewoziła” przez granicę. W przekazie jej podróży opisywano:

Pociag sanitarny francuski na dworcu „Cesarskim”. Panna Sokolnicka wciśnięta w tę gromadę żegnającego tłumu. Cała noc poprzednio pracowała, uczyła się na pamięć wieści przeróżnych (...), papiery ukryte na piersi p. Sokolnickiej, w razie niebezpieczeństwa zniszczy je, ale... może się uda. Personel sanitarny raz jeszcze kontroluje cały pociag (...). Panna Sokolnicka w ostatniej chwili niepostrzeżona przez Francuzów ukryje się w pewnej ubikacji i przejedzie!73.

Zwrotne doniesienia przychodziły do Poznania na kartkach pocztowych $z$ pozornie niewinną treścią.

W czasie gdy Sokolnicka przewoziła meldunki do Szwajcarii, „koło lozańskie” - jak nazwano jej współtowarzyszki - pracowało nad uproszczeniem złożonego tajnego alfabetu. W momencie wybuchu powstania wielkopolskiego na przełomie 1918/1919 r. przewoziła przez front i zrewolucjonizowane Niemcy najnowsze wieści dla Komitetu Narodowego Polskiego ${ }^{74}$. Kolejne miesiące przyniosły jednak zmianę sytuacji politycznej i dalsze prace nad alfabetem straciły rację bytu. Zespół się rozwiązał, ale dynamicznie następujące zmiany w momencie zakończenia wojny nie były końcem jej działalności politycznej. Kontynuowała ja już w nowych realiach, jawnie. 17 listopada 1918 r., w kilka dni po podpi-

\footnotetext{
73 Ibidem.

74 K. Dembski, Wielkopolska $w$ poczatkach II Rzeczypospolitej. Zagadnienia prawnoustrojowe, Poznań 1972, s. 96.
} 
saniu aktu zakończenia wojny, zwołano masowy wiec kobiet, który uznano za poczatek pracy politycznej $w$ odrodzonej Ojczyźnie ${ }^{75}$.

Od 3 do 5 grudnia 1918 r. w Poznaniu odbywały się obrady Polskiego Sejmu Dzielnicowego. Sokolnicka aktywnie włączyła się zarówno w prace przygotowujące, jak również wzięła w nim udział jako delegatka (jedna ze 141 posłanek) $z$ okręgu poznańskiego ${ }^{76}$. Weszła w skład Naczelnej Rady Ludowej w Poznaniu77, gdzie pełniła funkcje przewodniczącej Komisji dla Szkolnictwa Średniego Żeńskiego Wydziału Szkolnego NRL oraz członka Komisji Szkolnej Rady Ludowej miasta Poznania.

W 1919 r. przebywała w Paryżu i weszła w skład grupy ekspertów, $z$ pomocy których korzystał Komitet Narodowy Polski i polska delegacja w czasie konferencji pokojowej78. W jednym z (zaszyfrowanych) listów przesłanych z Paryża w styczniu 1919 r. pisała:

Miałam już pośrednią sposobność wzięcia w obronę (przemawiania za) naszą sprawę przed Wilsonem, któremu prześle się jutro materiał odnośny przez jego pełnomocników.

Cieszę się bardzo $z$ zobaczenia się jeszcze $z$ prezydentem Francji, który wyjeżdża już za kilka dni. Co słychać w Polsce? Jaki jest ogólny stan w Niemczech? Trzeba starannie pielęgnować ogólny stan naszej sprawy (...) itd. Pisane w Paryżu w styczniu r[oku] $1919^{79}$.

W czasie wojny o wschodnie granice Polski zainicjowała utworzenie Komitetu niesienia pomocy dla Lwowa, Wilna i Kresów Wschodnich, a w 1920 r., podczas najazdu bolszewickiego, Narodowa Służbę Kobiet w Poznaniu i Warszawie. Brała również aktywny udział w pracach plebiscytowych na Górnym Sląsku, dokąd przez kilka miesięcy dojeżdżała $z$ Warszawy.

75 M.H. Łebińska, Dziesięciolecie pracy politycznej kobiet $w$ Wielkopolsce, KP 1928, nr 518, s. 8.

76 Dziennik Polskiego Sejmu Dzielnicowego w Poznaniu, $w$ grudniu 1918, aneks: Spis delegatów wszystkich dzielnic zaboru pruskiego, Poznań 1918, s. 136.

77 Ibidem, s. 91-93.

78 K. Dembski, op. cit., s. 96 i n.

${ }^{79} Z$ Archiwum Zofii Sokolnickiej..., op. cit., s. 7. 
W listopadzie 1918 r. wraz z grupa przyszłych parlamentarzystek założyła Narodową Organizację Kobiet. Zgodnie ze statutem organizacja obejmowała swym zasięgiem całą Polskę, zakładano całkowite równouprawnienie kobiety $w$ ustawach $i w \dot{z} y c i u^{80}$. Sokolnicka była dwukrotnie wybierana do parlamentu $z$ Poznania $z$ ramienia Zjednoczonego Stronnictwa Ludowego i Narodowej Demokracji81 - w 1919 r. na Sejm Ustawodawczy i w 1922 r. na Sejm I kadencji. Pracowała w kilku komisjach: oświatowej, opieki społecznej, administracyjnej oraz emigracyjnej ${ }^{82}$. Na forum Izby wystapiła dziewiętnaście razy, przedstawiła czternaście interpelacji i dwanaście wniosków ${ }^{83}$.

W Zarysie sprawozdania za lata 1919-1927 informujacym o działalności posłanek Narodowej Organizacji Kobiet, podsumowując działalność poselską Sokolnickiej, zapisano:

Zawsze pełna skromności i gotowa do każdej pracy przyjęła mandat poselski, nie jako godność i wywyższenie, ale jako odpowiedzialny obowiazek do spełnienia. Była ona w Sejmie Ustawodawczym, jak również i w drugim jedną $z$ najbardziej pracowitych, a zarazem najbardziej w cień usuwających swą osobę posłanek, zajęta praca w Komisji Oświatowej i Spraw Zagranicznych. Była ona wybitna znawczynia spraw i stosunków wielkopolskich i wiedza swa oraz praca przyczyniała się $\mathrm{w}$ wysokim stopniu do wzmocnienia podstaw państwowości polskiej84.

\footnotetext{
80 Statut Stowarzyszenia: Narodowa Organizacja Kobiet, Warszawa 1921, zob. art. 1 i 2 a,d.

81 Parlament Rzeczypospolitej..., op. cit., s. 112; Kobieta w Sejmie: działalność posłanek Narodowej Organizacji Kobiet. Zarys sprawozdania za lata 1919-1927, Warszawa 1928, s. 8-11; T. Rzepecki, W. Rzepecki, Sejm i Senat 1922-1927. Podręcznik dla wyborców, zawierajacy wyniki wyborów w powiatach, okręgach, województwach, podobizny senatorów i posłów sejmowych oraz mapy pogladowe, Poznań 1923, s. 250-251.

82 Z. Sokolnicka, Aneks - parlamentarzystki Drugiej Rzeczypospolitej [online] [Dostęp: 31.08.2006]. Dostępny w World Wide Web: <http://kronika.sejm.gov.pl> (tu wyszczególniono daty i tematy jej wystapień).

83 Ibidem.

${ }^{84}$ Kobieta $w$ Sejmie..., op. cit., s. 10-11.
} 
Zmarła 27 lutego 1927 r. w Poznaniu. Nie założyła rodziny. W artykule opublikowanym $z$ okazji dziesięciolecia traktatu wersalskiego, wspominając Sokolnicka, spostrzeżono:

Wśród tych, którzy przygotowali niepodległość Polski, złotemi głoskami jaśnieć będzie po wszystkie czasy imię kobiety - Wielkopolanki, zgasłej już po trudach długiego dnia roboczego: Zofji Sokolnickiej!85.

W 1933 r. została pośmiertnie odznaczona Krzyżem Niepodległości. Jak zapisano w uzasadnieniu: Za wybitne zasługi $w$ organizowaniu tajnego szkolnictwa, strajków szkolnych $i$ harcerstwa wokresie powstańczym ${ }^{86}$. W $1948 \mathrm{r}$. jej prochy przeniesiono na Cmentarz Zasłużonych na Wzgórzu św. Wojciecha, gdzie spoczywaja do dnia dzisiejszego. W 1973 r. Rada Narodowa Poznania jedna $z$ ulic w dzielnicy Podolany nazwała jej imieniem.

Działacze Ligi weszli do wszelkich instytucji oraz organizacji politycznych, które powstawały w zaborze pruskim. $Z$ coraz większym zaangażowaniem uczestniczyły w nich także kobiety ${ }^{87}$. Jak zauważył Jakóbczyk, podejmowane działania doprowadziły do przemian $\mathrm{w}$ świadomości narodowej wielkopolskiego społeczeństwa i transpozycji dawnego ustroju feudalnego w nowoczesny naród ${ }^{88}$, o czym świadczyć może masowy udział w zwycięskim zrywie niepodległościowym - w powstaniu wielkopolskim ${ }^{89}$.

$85 Z$ archiwum Zofii Sokolnickiej..., op. cit., s. 7 .

86 Centralne Archiwum Wojskowe, Akta personalne: Zofia Sokolnicka, KN 25.07.1933.

87 Zob. G. Wyder, Żeński ruch skautowski $w$ Poznańskiem $w$ relacjach jego organizatorek $i$ uczestniczek $w$ latach 1912-1918, „Studia Zachodnie” 2011, t. 13, s. $165-182$.

88 W. Jakóbczyk, Sytuacja społeczno-polityczna $w$ Poznańskiem na przełomie XIX i XX wieku [w:] Wydarzenia wrzesinskie w roku 1901, red. Z. Grot, Poznań 1964, s. 41.

89 G. Wyder, Pamięć o Powstaniu Wielkopolskim w relacjach jego uczestniczek [w:] Pamięć historyczna kobiet, red. M. Przeniosło, K. Sierakowska, Kielce 2009, s. 39-52; Eadem, Szli wtedy wszyscy... Powstanie Wielkopolskie w przekazach jego uczestniczek, „Kronika Miasta Poznania” 2011, nr 1, s. 97-110. 


\section{Bibliografia}

\section{Źródła}

Archiwum Państwowe w Poznaniu, Akta betreffend den „Goniec Wielkopolski”, Wycinki prasowe Polizei Präsidium, sygn. 7266.

Archiwum Państwowe w Poznaniu, Polizei Präsidium Posen [Prezydium Policji w Poznaniu], sygn. 3681: Zofia Rzepecka.

Archiwum Polskiej Akademii Nauk w Poznaniu, Spuścizna prof. Z. Wojciechowskiego. Notatki Mariana Seydy dla Zygmunta Wojciechowskiego do pracy o historii Ligi Narodowej, spisane w r. 1932, sygn. P.III-8, odpis.

Archiwum Zarządu Okręgowego ZBOWiD w Poznaniu, sygn. 800, L. Gomolec, Przygotowania do powstania wielkopolskiego.

Centralne Archiwum Wojskowe, Akta personalne: Zofia Sokolnicka, KN 25.07.1933.

Materiały Archiwum Rodziny Sokolnickich, Pamiętnik Witolda Sokolnickiego, mps.

Zbiory Specjalne Biblioteki Raczyńskich w Poznaniu, Akta Towarzystwa Warta, Protokół z[e] zwyczajnego posiedzenia Towarzystwa „Warta” z dnia 2 października 1895, sygn. 1034.

Zbiory Specjalne Biblioteki Raczyńskich w Poznaniu, Akta Towarzystwa Warta, Protokół z „Pogadanki Pedagogicznej” odbytej dnia 30-go kwietnia [18]97 r. w „Czytelni dla Kobiet”, sygn. 1034.

Zbiory Specjalne Biblioteki Raczyńskich w Poznaniu, Bernard Chrzanowski, Z Towarzystwa Czytelni Ludowych, „Pamiętniki”, cz. 1, sygn. $1375 / \mathrm{e}-\mathrm{IV}$.

Zbiory Specjalne Biblioteki Raczyńskich w Poznaniu, Bernard Chrzanowski, Wspomnienie, cz. 1, sygn. 1375/Ia.

Zbiory Specjalne Biblioteki Raczyńskich w Poznaniu, Brownsford Maria (21 III 1855 w Lubowiczkach pow. Gniezno - 29 X 1924 w Bialczu).

\section{Źródła drukowane}

Cegielska Paulina, Przechadzki po mieście: $z$ moich wspomnień, oprac. i wstęp Przemysław Matusik, seria: „Biblioteka Kroniki Miasta Poznania”, Poznań: Wydawnictwo Miejskie, 1997, ISBN 8390833611.

Dmowski Roman, Myśli nowoczesnego Polaka, wyd. 12, popr. uzup., Wrocław: Wydawnictwo Nortom, 2002, ISBN 83-85829-14-8. 
Dziennik Polskiego Sejmu Dzielnicowego w Poznaniu, w grudniu 1918. Aneks: Spis delegatów wszystkich dzielnic zaboru pruskiego, Poznań: Drukarnia i Księgarnia Św. Wojciecha, 1918.

Kobieta w Sejmie: działalność posłanek Narodowej Organizacji Kobiet: zarys sprawozdania za lata 1919-1927, Warszawa: Nakład Narodowej Organizacji Kobiet, 1928.

Kozicki Stanisław, Historia Ligi Narodowej (okres 1887-1907), Londyn: Myśl Polska, 1964.

Kozicki Stanisław, Pamiętnik 1876-1939, oprac., przedmowa i przypisy Marian Mroczko, Słupsk: Wydawnictwo Naukowe Akademii Pomorskiej w Słupsku, 2009, ISBN 979-83-7467-014-2.

Sokolnicka Zofia, O pracy tajnej Towarzystwa Tomasza Zana pod jarzmem pruskim. Kilka wspomnień, seria: „Biblioteka Filomacka”, t. 3, Warszawa 1921.

\section{Źródla prasowe}

Alfabet Zofii Sokolnickiej, „Kurier Poznański” 1928, nr 518.

Klementowski, ks., Śp. Romana z Gex'sów Rzepecka, „Kurier Poznański” 1918, nr 72.

Ku uczczeniu śp. Heleny Rzepeckiej, „Kurier Poznański” 1916, nr 118.

Łebińska M.H., Dziesięciolecie pracy politycznej kobiet $w$ Wielkopolsce, „Kurier Poznański” 1928, nr 518.

Mowa panny Heleny Rzepeckiej, cz. 2: Zadanie Polki wobec dwóch nowych ustaw, „Głos Wielkopolanek” 1908, nr 9.

Pierwszy kurs społeczny dla kobiet, „Głos Wielkopolanek” 1908, nr 36.

[Senior] A., [Dmowski Roman], Poczatki nowoczesnego obozu narodowego w Polsce, „Myś1 Narodowa” 1936, nr 47.

Sprawozdanie z działalności Ligi w r. 1895/1896, „Niepodległość” 1933, t. 7 .

Sprawozdanie z działalności Ligi Narodowej od 1 lipca 1903 do 1 lipca 1904, „Niepodległość” 1934, t. 10.

Sprawozdanie za rok 1900-1901, „Niepodległość” (styczeń 1934 - czerwiec 1934), t. 9.

Śp. Felicjan Niegolewski, „Kurier Poznański” 1919, nr 7.

Śp. Helena Rzepecka, „Kurier Poznański” 1916, nr 117.

Śp. Zofia Sokolnicka, „Kurier Poznański” 1927, nr 94.

Walny wiec kobiet $w$ Poznaniu, cz. 1, „Kurier Poznański” 1908, nr 112; cz. 2, „Kurier Poznański” 1908, nr 113.

Walny wiec kobiet $w$ Poznaniu, 12 maja 1908 r., „Dziennik Poznański” 1908, nr 109. 
Z Archiwum Zofii Sokolnickiej. W dziesięciolecie Traktatu Wersalskiego, „Kurier Poznański” 1929, nr 294.

Zakopane - Zjazd, „Kurier Poznański” 1899, nr 188; „Kurier Poznański” 1899, nr 190.

\section{Zasoby internetowe}

Sokolnicka Zofia, Aneks - parlamentarzystki Drugiej Rzeczypospolitej [Dostęp: 31.08.2006]. Dostępny w World Wide Web: $<$ http://kronika.sejm.gov.pl>.

Hasło: Niegolewscy, h. Grzymała [w:] Teki Dworzaczka. Materiały historyczno-genealogiczne do dziejów szlachty wielkopolskiej XV-XX wieku, Kórnik-Poznań 2004 [Dostęp: 03.05.2017]. Dostępny w World Wide Web: < http://teki.bkpan.poznan.pl/>.

\section{Opracowania}

Czyżowski Tadeusz, Wincenty. Lutosławski (1863-1954) [w:] Polski Słownik Biograficzny, t. 18, red. Emanuel Rostworowski, Wrocław: Zakład Narodowy im. Ossolińskich, 1973.

Dembski Krzysztof, Wielkopolska w poczatkach II Rzeczypospolitej, Zagadnienia prawnoustrojowe, Poznań 1972.

Dworecki Zbigniew, Poznańskie i Piłsudski, seria: „Wielkopolska”, Poznań: Wydawnictwo Poznańskie, 2008, ISBN 9788371774850.

Halczak Bohdan, Towarzystwo Tomasza Zana w latach 1899-1914, Zielona Góra: WSP, 1996, ISBN 838683207X.

Hulewicz Bohdan, Wielkie wczoraj $w$ małym kregu, Warszawa: Instytut Wydawniczy Pax, 1968.

Jakóbczyk Witold, Prasa w Wielkopolsce (1859-1918) [w:] Prasa polska $w$ latach 1864-1918. Historia prasy polskiej, red. Jerzy Łojek, Warszawa: PWN, 1976.

Jakóbczyk Witold, Sytuacja społeczno-polityczna $w$ Poznańskiem na przełomie XIX i XX wieku [w:] Wydarzenia wrzesinskie w roku 1901, red. Zdzisław Grot, Poznań: Wydawnictwo Poznańskie, 1964.

Kaczmarek Zygmunt, Sokolnicka Zofia [w:] Wielkopolski Słownik Biograficzny, red. Antoni Gąsiorowski, Warszawa-Poznań: PWN, 1981.

Karwat Janusz, Od idei do czynu: myśl $i$ organizacje niepodległościowe $w$ Poznańskiem $w$ latach 1887-1919, Poznań: Wydawnictwo Poznańskie, 2002, ISBN 8371770855.

Kras Janina, Wyższe kursy dla kobiet im. A. Baranieckiego w Krakowie 1968-1924, Kraków: Wydawnictwo Literackie, 1927. 
Łukomski Grzegorz, Bernard Chrzanowski (1861-1944): biografia Polaka zachodniokresowego, Poznań-Opalenica: Opalgraf, 2005, ISBN 8392051193.

Drogi kobiet do polityki (na przestrzeni XVIII-XXI wieku), red. Teresa Kulak, Małgorzata Dajnowicz, Wrocław: Wydawnictwo Chronicon, 2016, ISBN: 788394616625.

Marczewski Jerzy, Narodowa Demokracja w Poznańskiem 1900-1914, Warszawa: PWN, 1967.

Marian Kiniorski [w:] Ziemianie polscy XX w. Słownik biograficzny, t. 2, red. Janina Leskiewiczowa, Warszawa 1994.

Męczyńska Katarzyna, Romana Rzepecka, jej córki i gosposia, „Kronika Miasta Poznania" 2011, nr 1.

Molik Witold, $Z$ badan nad studiami uniwersyteckimi Wielkopolanek na przełomie XIX i XX wieku [w:] Kobieta i edukacja na ziemiach polskich $w$ XIX i XX wieku, t. 2, cz. 2, red. Anna Żarnowska, Andrzej Szwarc, Warszawa: DIG, 1992, ISBN 8385490248.

Parlament Rzeczypospolitej Polskiej 1919-1927, red. Henryk Mościcki, Włodzimierz Dzwonkowski, Warszawa: Wyd. Lucjan Złotnicki, 1928.

Perkowska Urszula, Studentki Uniwersytetu Jagiellońskiego $w$ latach 1894-1939. W stulecie immatrykulacji pierwszych studentek, Kraków: Secesja, 1994, ISBN 8386077514.

Rzepecka Helena, Ojczyzna w piśmie i pomnikach, t. 2, Poznań: Drukarnia „Dziennika Poznańskiego”, 1911.

Serwatka Bernadeta, Zofia Sokolnicka - nauczycielka i działaczka społeczna (1878-1927), praca mag., Uniwersytet im. Adama Mickiewicza w Poznaniu, Poznań 1993.

Słowiński Lech, Działalność oświatowa i społeczna Heleny Rzepeckiej (1863-1916) [w:] Lech Słowiński, Będziem Polakami: studia z dziejów edukacji narodowej $w$ Wielkim Księstwie Poznańskim, Poznań: Wydawnictwo Poznańskiego Towarzystwa Przyjaciół Nauk, 1995.

Słowiński Lech, Helena Rzepecka [w:] Polski Słownik Biograficzny, t. 34, red. Emanuel Rostworowski, Wrocław: Zakład Narodowy im. Ossolinskich, 1992-1993.

Słowiński Lech, $Z$ dziejów walki o tożsamość narodowa pod pruskim zaborem. Działalność oświatowa $i$ społeczna Heleny Rzepeckiej (18631916), „Kronika Miasta Poznania” 1994, nr 3/4.

Trzeciakowski Lech, Pod pruskim zaborem 1850-1918, Warszawa: Wiedza Powszechna, 1973.

Wyder Grażyna, Pamięć o Powstaniu Wielkopolskim $w$ relacjach jego uczestniczek [w:] Pamięć historyczna kobiet, red. Marek Przeniosło, 
Katarzyna Sierakowska, Kielce: Wydawnictwo Uniwersytetu Humanistyczno-Przyrodniczego Jana Kochanowskiego, 2009.

Wyder Grażyna, $Z$ dziejów walki o tożsamość narodowa - tajne stowarzyszenie Kobiet „Warta” [w:] Polacy - Niemcy - Pogranicze. Studia Historyczne, red. Grażyna Wyder, Tomasz Nodzyński, Zielona Góra: Oficyna Wydawnicza Uniwersytetu Zielonogórskiego, 2006.

\section{Publicystyka prasowa}

Wyder Grażyna, Szli wtedy wszyscy... Powstanie wielkopolskie w przekazach jego uczestniczek, „Kronika Miasta Poznania” 2011, nr 1.

Wyder Grażyna, Żenski ruch skautowski w Poznańskiem w relacjach jego organizatorek i uczestniczek w latach 1912-1918, „Studia Zachodnie” 2011, t. 13, ISSN 1428-0663. 